\title{
Morphology, RNase and transaminase of root protoplasts
}

\author{
Paul-Emile Pilet, Roger Prat and Jean-Claude Roland \\ Institute of Plant Biology and Physiology, University of Lausanne, \\ Switzerland and Laboratory of Plant and Cell Biology, \\ University of Paris VI, France
}

(Received November 22, 1971)

\begin{abstract}
RNase and transaminase activities were analysed for mechanically and enzymatically prepared protoplasts from Allium Cepa roots. The comparative analyses at three root regions show that the enzymes were less active in the protoplasts than in the cells from which they had been obtained. The enzyme gradients (from apex to base of the root: RNase increase and transaminase decrease) noted previously in the intact roots were found to be similar in the protoplasts, however to a lesser degree. On the other hand, the relative activity of both tested enzymes was lower in the enzymatically prepared protoplasts than in those obtained by the mechanical technique. In connection with their physiological properties, the respective effects of the mode of preparing the protoplasts were discussed.
\end{abstract}

The first original technique for preparing protoplasts from higher plant cells (1) was progressively improved and adapted for fruits (2), leaves (3) and tissues cultivated in vitro $(4,5)$. All the methods proposed were based on the enzymatic destruction of the cell walls (6). Meanwhile, in a few old papers (7-9), a mechanical method was presented; it also allows obtaining protoplasts from plant cells. Furthermore, a few attempts regarding root protoplasts should be mentioned. Among the numerous papers related to protoplasts, the greater part is devoted to the study of their structure (10) and their ultrastructure (11-13). Only a few of them involve their physiology (14) and the properties of their enzymes (15). It should still be noted that most papers did not compare protoplasts and the cells from which they had been prepared.

In the present paper, the following problems will be discussed:

1) several properties of root protoplasts;

2) comparison between two methods (enzymatic and mechanical techniques) of obtaining protoplasts;

3) analysis - for both types of protoplasts obtained - of the RNase and transaminase activities;

4) observation of the consequences of the cell differentiation, for cells and protoplasts which derive from these cells. 


\section{Material and methods}

Preparation of roots

Roots of Allium Cepa - from fresh bulbs - were cultivated in running water (light, $25 \pm 2^{\circ} \mathrm{C}$ ). When they were $10 \pm 1 \mathrm{~cm}$, the entire roots were plasmolysed in a water solution of $20 \%$ sucrose or in a mineral solution (16) of $20 \%$ sucrose. During the incubation ( $2 \mathrm{hr}$ ), osmotic pressure was raised by adding $\mathrm{NaCl}(1.2 \%)$. Then, $1 \mathrm{~cm}$ long segments were cut at three different regions: (level $A$, starting from the root tip: $0.5-1.5 \mathrm{~cm}$; level $B, 4.5-5.5 \mathrm{~cm}$; and level $C, 9.0-10.0 \mathrm{~cm})$. At each stage of the assay, a few segments were set apart for microscopical analyses.

Observations will be reported on 1) living preparations in phase contrast without stain, 2) permanent preparation, after fixing in formol-acetic acid-ethanol embedding in paraffin and stain with periodic acid, Schiff reactive and hematoxylin. Photographs were made with a Zeiss photomicroscope (Adox KB 14 film). Size measurements were done on enlarged photographs.

\section{Preparation of cells}

In order to express the RNase and transaminase activities of the root extracts, and to compare this activity to protoplast cells, it was necessary to report it to a given number of cells (17). Preliminary assays permitted (for root segments - regions A, B and C) the determination of the number of cells as regards a given fresh weight. These root segments were at first fixed in the Navachine mixture (18), then incubated in a pectinase (Citrus preparation) solution (19). After centrifugation $\left(3 \cdot 10^{3} \times g\right.$ : $10 \mathrm{~min}$ ), the cells were counted.

\section{Preparation of protoplasts}

For isolating the protoplasts, two different methods were used and compared (mechanical and enzymatical techniques).

Mechanical method: it has been reported previously $(20,21)$ for a similar material. Parallel bundles of 10 to 20 calibrated fractions of roots were cut with a razor blade on a glass slide. The sectioning must be done as quickly and as closely as possible. Each thin root section produced, on both faces, protoplasts floating on the medium surface. Some drops of the mineral solution with $20 \%$ sucrose were poured on the sections. Protoplasts were then drained in small containers. They were carried by capillarity in a ring made of a sheet of polystyrene (hole $2 \mathrm{~mm}$ diameter). Four washings were done with $20 \%$ sucrose solution before starting the analyses. Fig. 1 shows the instrument used for collecting a large number of protoplasts along the axis of the root (and specially at the regions A, B and C). Approximately 20 roots were placed, side by side, on the support (5); they were quickly cut - as described before. After washing with the mineral solution and sucrose, protoplasts were collected in a series of tubes $(T)$ related to the position of root segments. They fell into small tubes $\left(T_{1}\right)$ for a quick and non purified preparation. Large tubes $\left(T_{2}\right)$ can also be used. Intact protoplasts rise progressively to the upper surface (20) and they were collected easily.

Enzymatical method: a single enzymatic treatment - according to a technique derived from those previously proposed by Power and Cocking (22) and Nagata and 

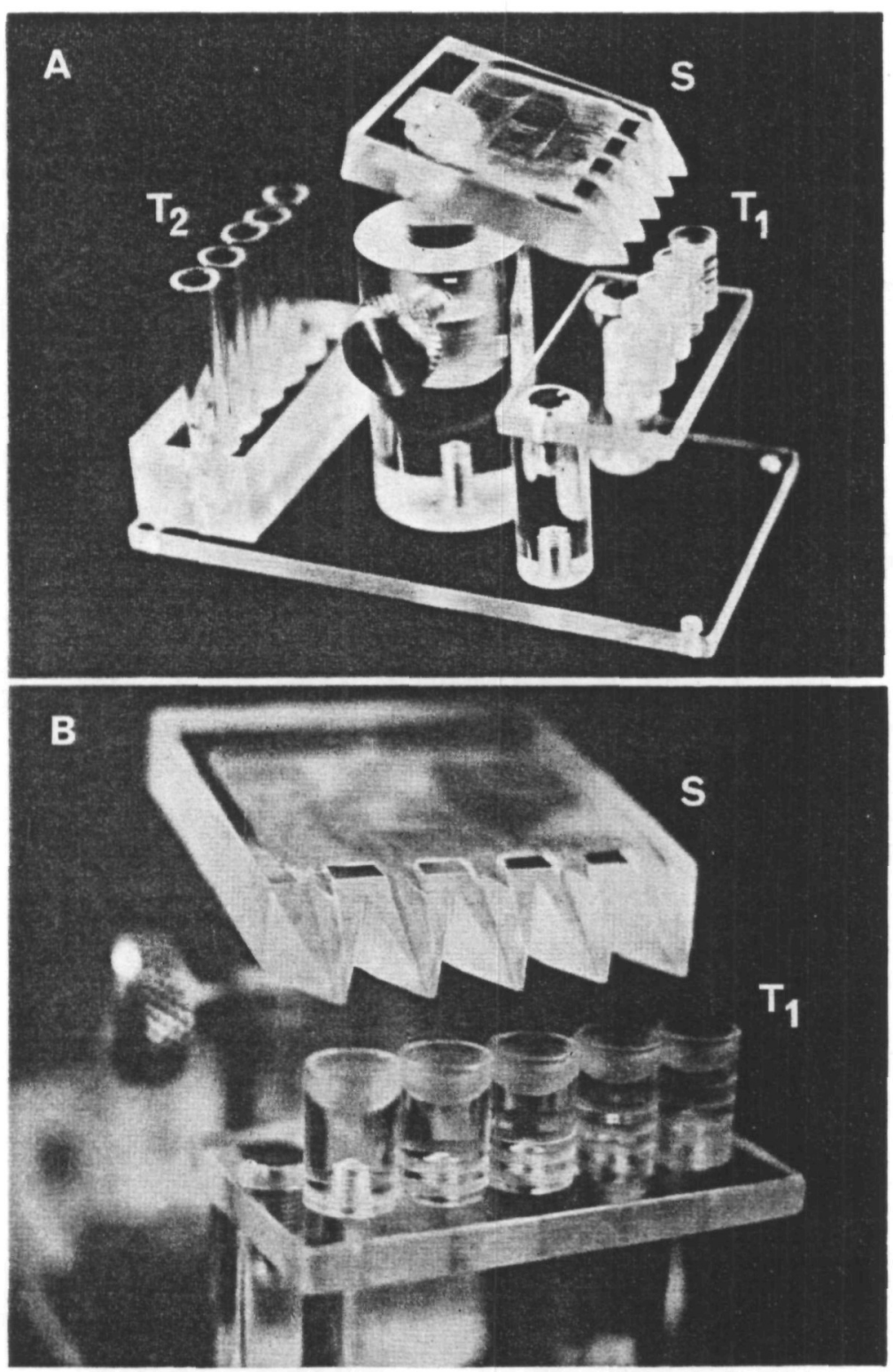

Fig. 1. Diagram showing the apparatus employed for the isolation of protoplasts mechanically prepared from the $10 \mathrm{~cm}$ roots of Allium. $(\mathrm{A}, \times 1 / 2 ; \mathrm{B}, \times 1), \mathrm{T}_{1}$, tubes to collect the small fractions; $T_{2}$, tubes to collect the large fractions; $\mathrm{S}$, support for the roots.

Takebe (23) rather similar to the method recently used by Schmitt et al. (4) was employed. The incubation medium is the mineral solution with $20 \%$ sucrose to which 5\% macero-enzyme (Unwin, Herts) and 5\% cellulase Onozuka P 1500 (All Japan Biochem.) are added. The incubation time was approximately $12 \mathrm{hr}$ 


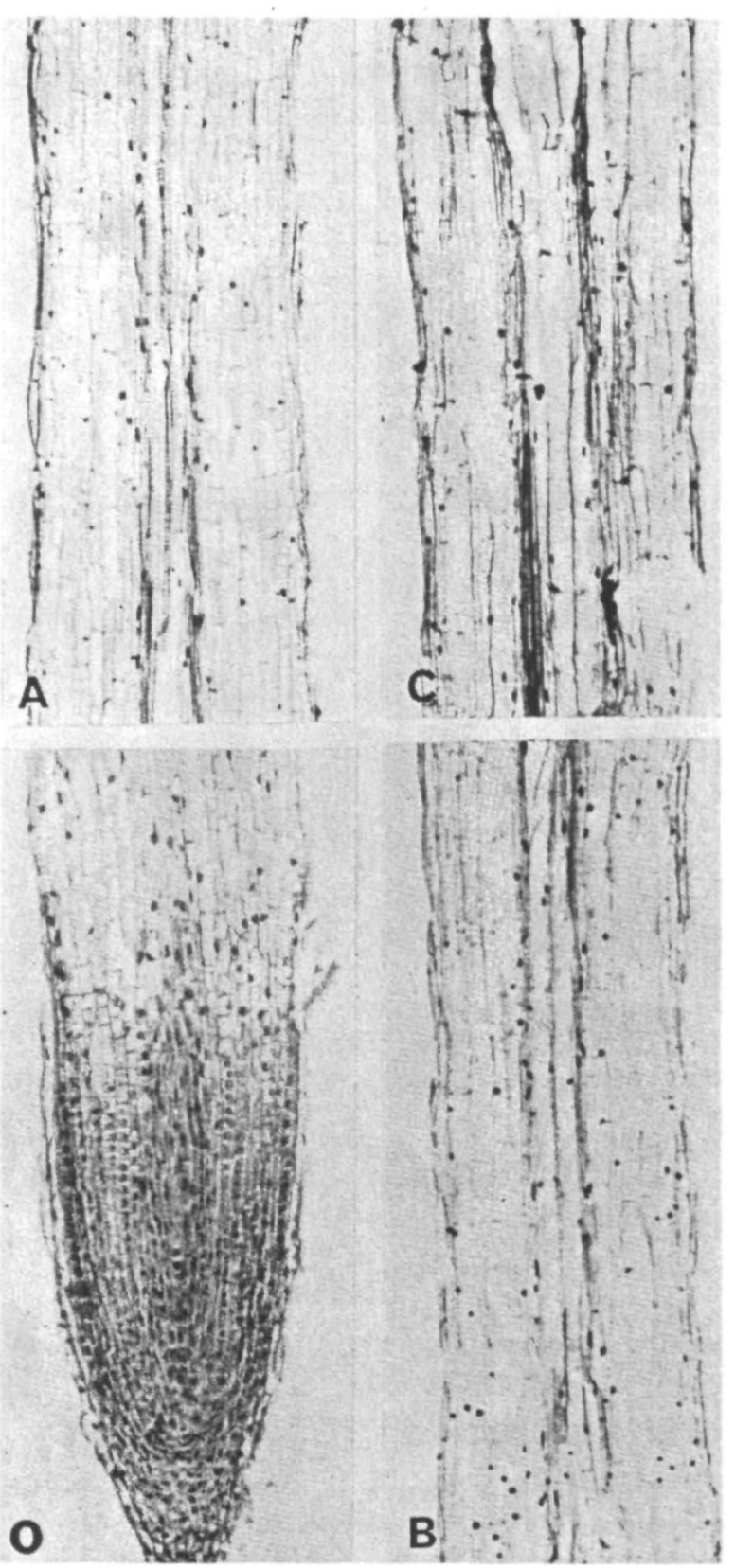

Fig. 2. Histological aspect of the abex $(O)$ and of the three regions $(A, B$ and $C$ ) of the $10 \mathrm{~cm}$ roots of Allium used for preparing the protoplasts $(\times 120)$. O: $0.0-0.2 \mathrm{~mm} ; \mathrm{A}: 0.5-1.5 \mathrm{~mm} ; \mathrm{B}: 4.5-5.5 \mathrm{~mm} ; \mathrm{C}: 9.0-$ $10.0 \mathrm{~mm}$. 
$\left(20^{\circ} \mathrm{C}\right)$. Several washings were done with the mineral solution and $20 \%$ sucrose.

Enzyme activities

RNase. The method was previously described by Pilet and Braun (24). Root fragments or protoplasts suspension were ground with $0.1 \mathrm{~m}$ ammonium acetate buffer $\mathrm{pH} 5.0$. The homogenate was centrifuged $(12,000 \times \mathrm{g} ; 30 \mathrm{~min})$ and the supernatant diluted. Then, assays were performed in a manner similar to that previously described (25). To $1 \mathrm{ml}$ RNA, $0.5 \mathrm{ml}$ extract was added; after an incubation $\left(30 \mathrm{~min} ; 37^{\circ} \mathrm{C}\right)$, the undegraded RNA was precipitated by perchluric acid. The supernatants were diluted and their optical density (OD) was measured at $260 \mathrm{~nm}$. The difference between the controls absorbancy and the incubated samples was taken as a measurement of RNase activity expressed in terms of OD. Transaminase. Only the GOT transaminase system (glutamic-oxaloacetic), the activity of which is particularly high for plant cells (26) - was tested here. The technique used was first proposed by Pilet and Athanasiades (27) for root extracts. Our method is based on the spectrophotometric analyses (492 $\mathrm{nm}$ ) of the coloured hydrazones, using a pyruvate standard. Activity was tested for the protoplasts used immediately after the preparation. Conditions of enzyme incubation $(60 \mathrm{~min}$, $\left.37^{\circ} \mathrm{C}\right)$ are those previously fixed for the root extracts $(28,31)$.

\section{Results}

\section{Morphological problems}

The structure (histology and cytology) of Allium Cepa growing root is well known (29). In the first $\mathrm{mm}$ of the tip, the presence of the root cap, the quiescent center and the meristem can be noted (Fig. 2;O). The cellular differentiation and the elongation occur in the second and third $\mathrm{mm}$ of the root tip. At the $\mathrm{A}, \mathrm{B}$ and $\mathrm{C}$ regions, which are used for isolating the protoplasts (Fig. 2; A, B and C), the central cylinder is extremely small, with a relatively large number of dead cells. Protoplasts were mostly formed, for cortical parenchyma. The cells of this parenchyma are rather homogeneous, with a primary wall, large and central vacuoles, peripheric nuclei, mitochondria and plastids scattered in the cytoplasm.

After the plasmolysis, the protoplasm retracts and generally forms one or two spherical masses in the centre of the cell $(30)$. These masses were linked across their walls to each other and to neighbouring cells, by thin tractuss of protoplasm.

After mechanical isolation, numerous small subprotoplasts were produced, mostly in the young part of the root (level A, Fig. 3). Larger protoplasts $(>20 \mu$ ), with vacuoles and nucleus, were found in levels $B$ and $C$ (Fig. 4 and Fig. 5). However, the populations of enzymatically prepared protoplasts were always more homogenous for a similar region (for example, level B: Fig. 6) as compared to the protoplasts mechanically obtained (Fig. 4).

Such observations were confirmed by statistical data related to the differences in the size of protoplasts prepared by the two techniques. The size variability of the mechanically prepared protoplasts is shown in Fig. 7 in which the number of protoplasts was reported for several diameters (from 0 to $60 \mu$ ). If sizes of the protoplasts are compared, one can first notice (Fig. 8) that the number of small 

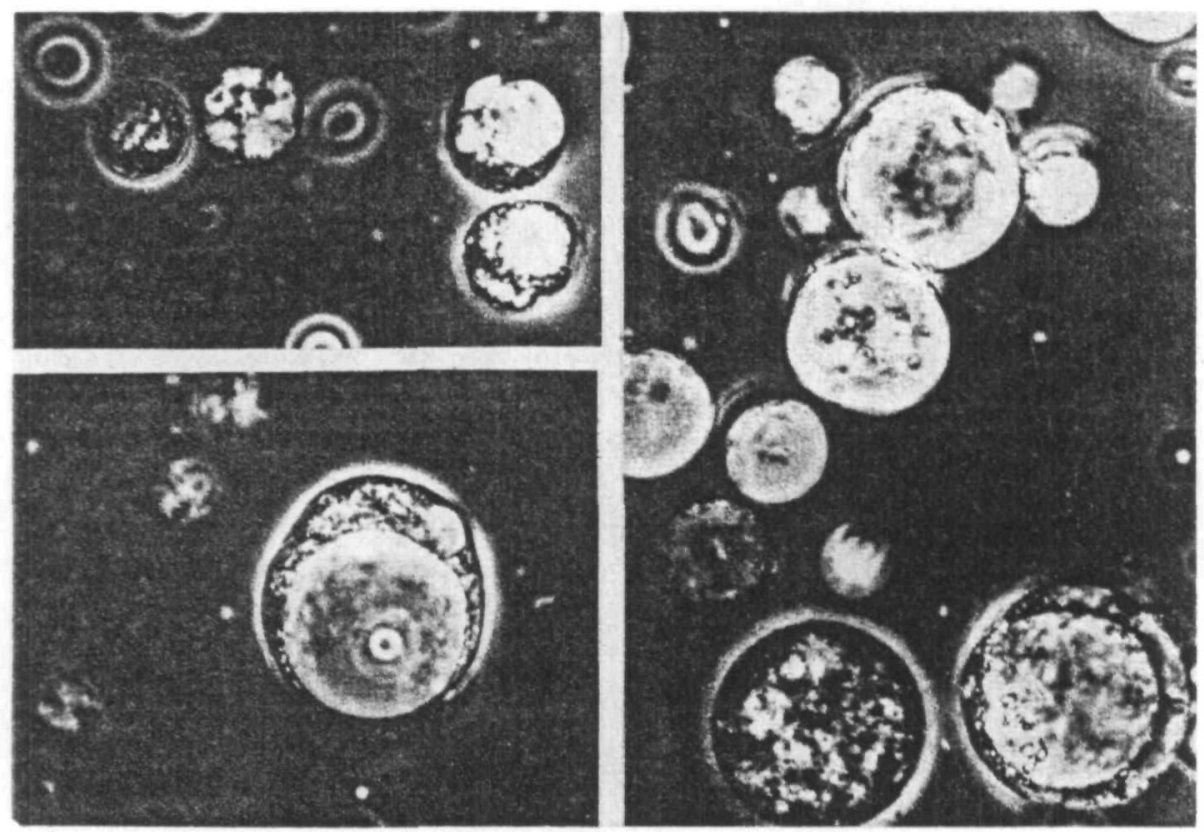

Fig. 3. Several kinds of protoplasts (Allium roots) mechanically prepared (Region A: see Fig. 2) $(\times 1,400)$.

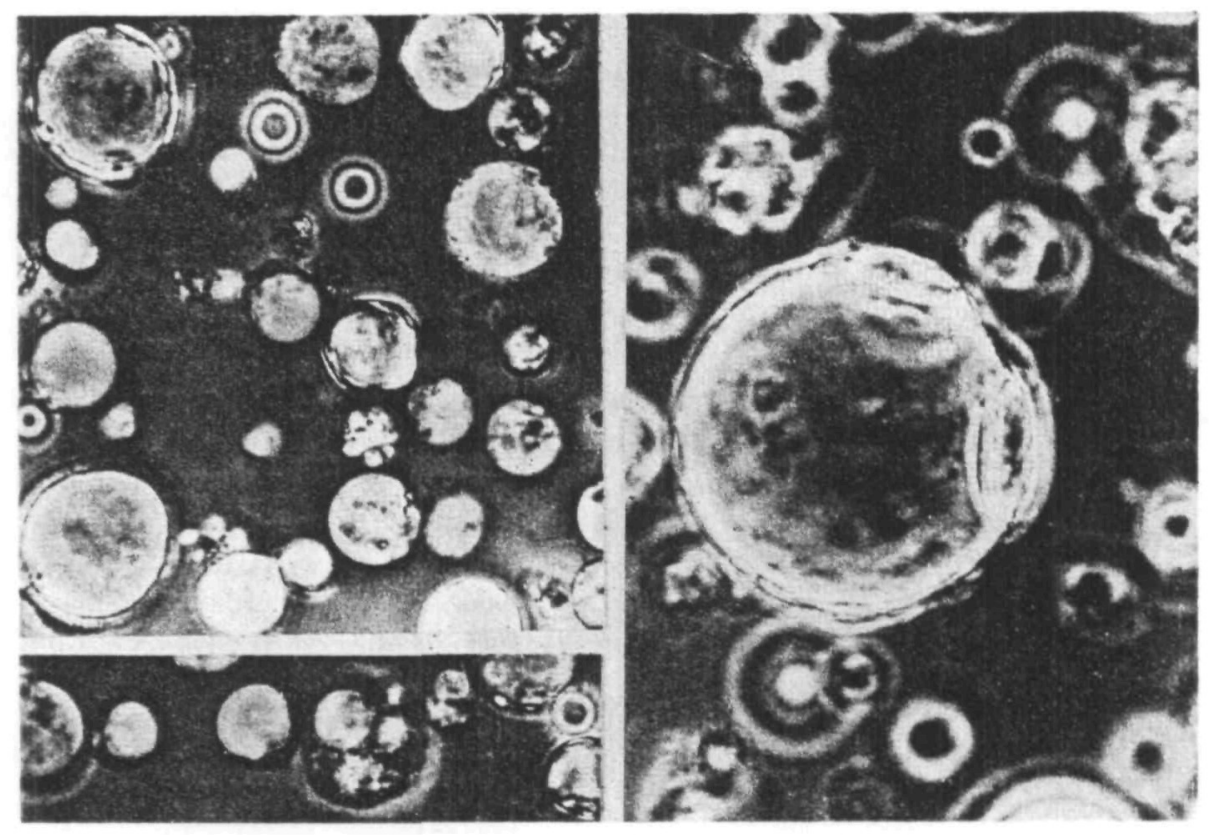

Fig. 4. Several kinds of protoplasts (Allium roots) mechanically prepared (Region B: see Fig. 2) $(\times 1,400)$. 

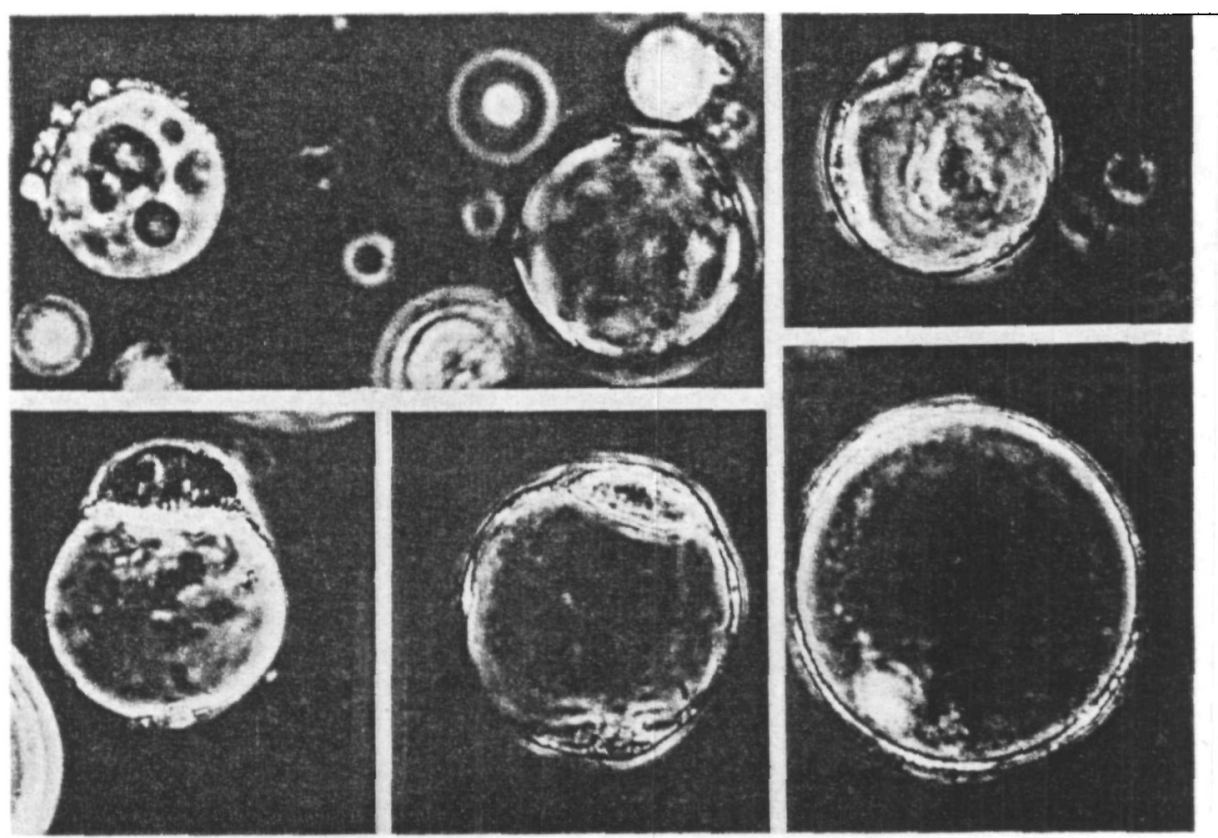

Fig. 5. Several kinds of protoplasks (Allium roots) mechanically prepared (Region C: see Fig. 2) $(\times 1,400)$.
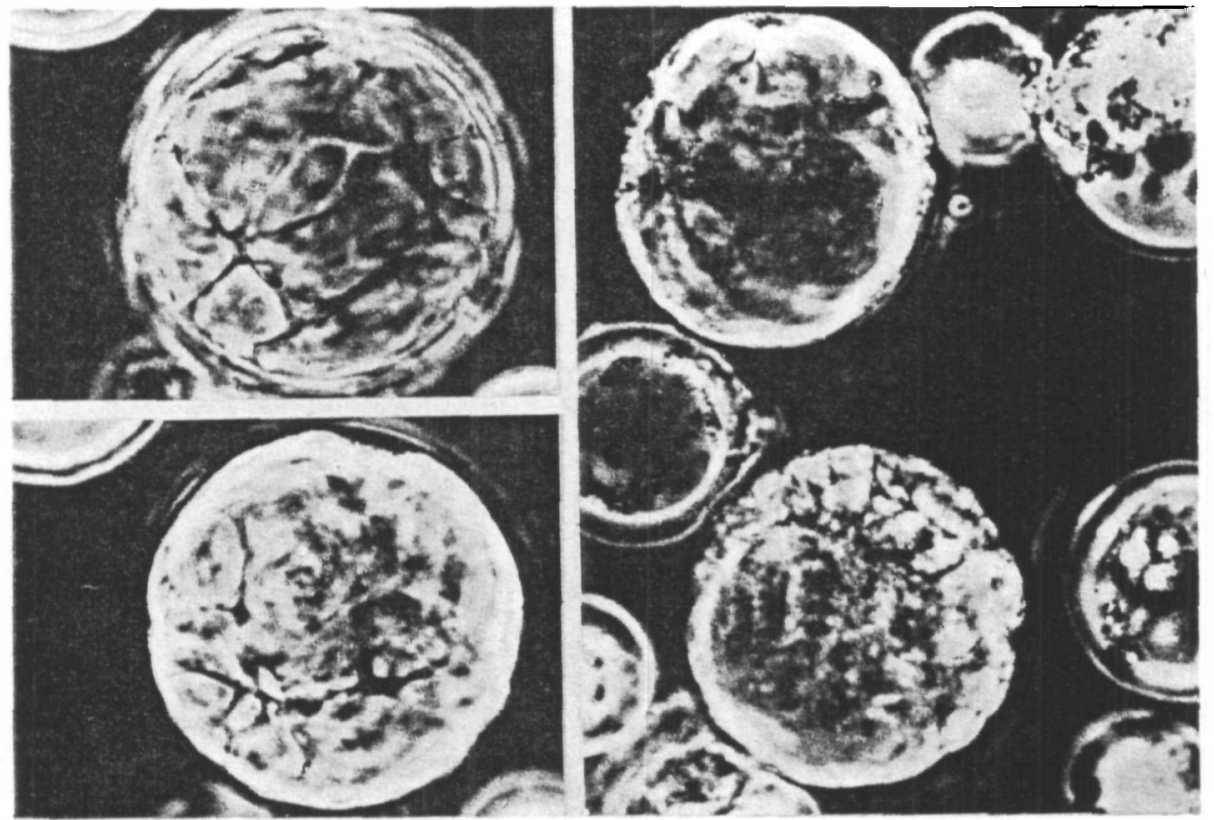

Fig. 6. Several kinds of protoplasts (Allium roots) enzymatically prepared (Region B: see Fig. 2 and Fig. 4) $(\times 1,400)$. 


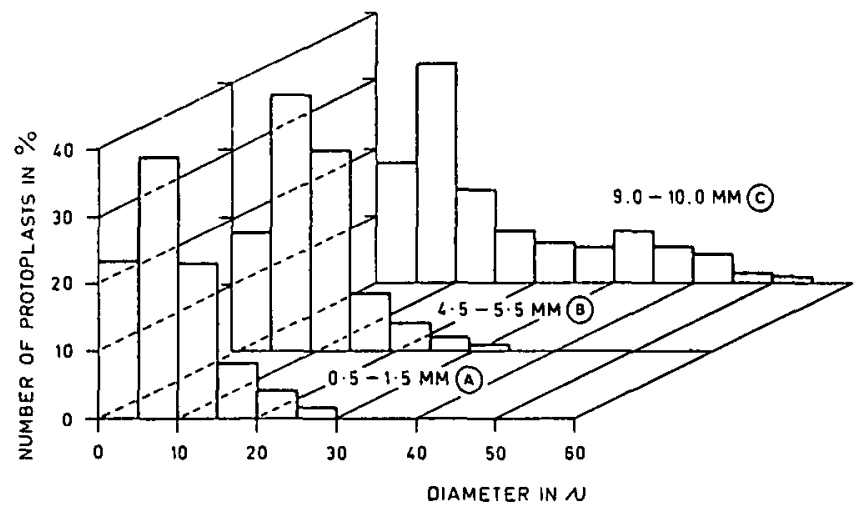

Fig. 7. Relative number (\%) of protoplasts (Allium roots) mechanically prepared as regard as regard their dianeter (in $\mu$ ). Protoplasts of the three regions (A, B and C; see Fig. 2) were analysed.

mechanical protoplasts is far larger than those of the enzymatic ones. On the other hand, the mean size of the enzymatical protoplasts is higher and the dispersion is also greater. It should be kept in mind, for all the root protoplasts, that since large $(>20 \mu)$ mechanically prepared protoplasts are nearly $2 / 3$ of the total volume, subprotoplasts are only a small part of the whole.

\section{Enzyme reactions}

Preliminary observations. The preparation of protoplasts implies previous plasmolysis. It was of interest to study, at first, the effects of plasmolysis on the activity of the two chosen enzymes. On the other hand, and for Lens roots, it has been noted that RNases (17) and transaminases (31) showed - from apex to the root bases - significant changes in their activities. It was thus interesting to check on the existence of such a gradient for the cells of Allium roots (32).

Plasmolysis is continued ( $2 \mathrm{hr}$ ) according to the above described method, and the activity of RNases and transaminases was analysed.

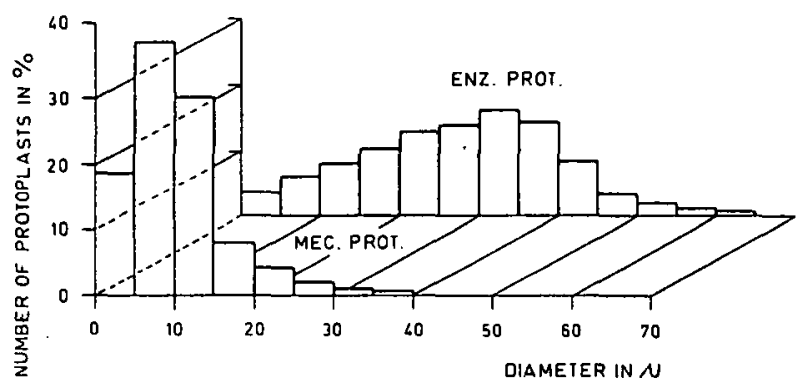

Fig. 8. Relative number (\%) of protoplasts (Allium roots) mechanically (MEC. PROT.) or enzymetically (ENZ. PROT.) prepared (Level B: see Fig. 2) in relation to their diameter (in $\mu$ ). 
Table 1

Comparative RNase activity of cells (control and after plasmolysis) prepared from the $10 \mathrm{~cm}$ roots of Allium

\begin{tabular}{ccc}
\hline \multirow{2}{*}{$\begin{array}{c}\text { Regions } \\
\text { (see Fig. 2) }\end{array}$} & \multicolumn{2}{c}{ Root cells } \\
\cline { 2 - 3 } A & $6.5 \pm 1.2$ & plasmolysed (2hr) \\
\hline B & $12.0 \pm 1.3$ & $6.9 \pm 1.7$ \\
C & $34.1 \pm 1.1$ & $10.5 \pm 2.0$ \\
& & $35.2 \pm 2.3$ \\
\hline
\end{tabular}

Each result is the average of 16 values.

The enzyme activity is expressed in terms of optical density $\left(\times 10^{2}\right)$ at $260 \mathrm{~nm}$ per $10^{7}$ cells.

Table 2

Comparative transaminase activity of cells (control and after plasmolysis) prepared from the $10 \mathrm{~cm}$ roots of Allium

\begin{tabular}{ccc}
\hline $\begin{array}{c}\text { Regions } \\
\text { (see Fig. 2) }\end{array}$ & control & Root cells \\
\cline { 2 - 3 } A & $84.5 \pm 3.2$ & $78.2 \pm 4.5$ \\
B & $55.2 \pm 3.0$ & $59.4 \pm 4.1$ \\
C & $33.7 \pm 2.7$ & $39.2 \pm 3.6$
\end{tabular}

Each result is the average of 12 (control) and 10 (plasmolysed) values.

The enzyme activity (GOT system) is expressed in $\mu \mathrm{g}$ equivalents $\left(\times 10^{-5}\right)$ of pyruvate formed by $10^{7}$ cells.

Table 3

Comparative RNase activity of protoplasts prepared from the $10 \mathrm{~cm}$ roots of Allium

\begin{tabular}{crc}
\hline \multirow{2}{*}{$\begin{array}{c}\text { Regions } \\
\text { (see Fig. 2) }\end{array}$} & \multicolumn{2}{c}{ Protoplasts } \\
\cline { 2 - 3 } A & mechanically prepared & enzymatically prepared \\
B & $4.2 \pm 1.7$ & $3.0 \pm 1.6$ \\
C & $5.9 \pm 2.0$ & $4.7 \pm 2.0$ \\
& $10.4 \pm 3.2$ & $6.1 \pm 2.7$
\end{tabular}

Each result is the average of 9 values.

The enzyme activity is expressed in terms of optical density $\left(\times 10^{2}\right)$ at $260 \mathrm{~nm}$ per $10^{7}$ protoplasts. Only protoplasts with a diameter $>$ to $15 \pm 2 \mu$ were counted. 
Table 4

\begin{tabular}{|c|c|c|}
\hline & \multicolumn{2}{|c|}{ Protoplasts } \\
\hline & $\begin{array}{c}\text { mechanically } \\
\text { prepared }\end{array}$ & $\begin{array}{l}\text { enzymatically } \\
\text { prepared }\end{array}$ \\
\hline $\begin{array}{l}\text { Mean volume in } \mu^{3} \text { per protoplast } \\
\text { (V) }\end{array}$ & $2,130^{*}$ & $9,412^{* *}$ \\
\hline $\begin{array}{l}\text { RNase activity in } 10^{2} \times \text { OD per } 10^{7} \\
\text { protoplasts }(A)\end{array}$ & 5.9 & 4.7 \\
\hline $10^{4} \times \mathrm{A} / \mathrm{V}$ & 27.7 & 4.9 \\
\hline
\end{tabular}

Protoplasts counted: $183^{*}$ and $127 * *$.

Only results for the region B (see Fig. 2) were reported.

The results for RNase, given in Table 1 , clearly show that 1 ) there is no significant difference between the activity of control and of plasmolysed cells; 2) the RNase activity was found to be increasing from region $A$ to region $C$.

For transaminase (Table 2) it can also be observed that the activity was similar for both the control and the plasmolysed cells. Transaminase activity showed, however, a significant decrease between region $\mathrm{A}$ and region $\mathrm{C}$.

Consequently, the distribution of the RNase and transaminase activities - not affected by plasmolysis - along the root axis of Allium Cepa shows a pattern similar to that previously observed for Lens roots $(17,27,31)$.

RNase. Results, for the two kinds of protoplasts, are reported in Table 3. One can notice that: 1) even though the mean values show stronger activity in the mechanically obtained protoplasts, at no region the differences are significant; 2) the gradient, observed in the case of the root cells (see Table 2) is still visible in the protoplasts but to a far lessened degree; 3 ) generally speaking, the protoplasts RNase are less active than those of root cells and the inhibition noted is all the more characteristic as the activity is higher, i.e. as the cells are more differentiated (region C).

The mean volume of the protoplasts is, however, not to be compared to that of the cells from which they issued and it differs - at the same region - according to whether the protoplast had been prepared mechanically or enzymatically. It is

Table 5

Comparative transaminase activity of protoplasts prepared from the $10 \mathrm{~cm}$ rooks of Allium

\begin{tabular}{ccc}
\hline $\begin{array}{c}\text { Regions } \\
\text { (see Fig. 2) }\end{array}$ & \multicolumn{2}{c}{ Protoplasts } \\
\cline { 2 - 3 } & prepared & $\begin{array}{c}\text { enzymatically } \\
\text { prepared }\end{array}$ \\
\hline A & $50.9 \pm 4.1$ & $41.0 \pm 4.2$ \\
B & $27.6 \pm 3.5$ & $24.1 \pm 3.2$ \\
C & $10.2 \pm 2.4$ & $7.9 \pm 2.7$ \\
\hline
\end{tabular}

Each result is the average of 14 values.

The enzyme activity is expressed in $\mu \mathrm{g}$ equivalents $\left(\times 10^{-5}\right)$ of pyruvate formed per $10^{7}$ protoplasts. Only protoplasts with a diameter $>$ to $15 \pm 2 \mu$ were counted. 
Table 6

Relative transaminase activity of protoplasts prepared from the $10 \mathrm{~cm}$ roots of Allium

\begin{tabular}{lcc}
\hline & \multicolumn{2}{c}{ Protoplasts } \\
\cline { 2 - 3 } & $\begin{array}{c}\text { mechanically } \\
\text { prepared }\end{array}$ & $\begin{array}{c}\text { enzymatically } \\
\text { prepared }\end{array}$ \\
\hline $\begin{array}{l}\text { Mean volume in } \mu^{3} \text { per protoplast } \\
\text { (V) }\end{array}$ & $2,004^{*}$ & $9,670^{* *}$ \\
$\begin{array}{l}\text { Transaminase activity in } 10^{-5} \times \mu \mathrm{g} \\
\text { eq. pyruvate per } 10^{7} \times \text { protoplasts }\end{array}$ & 27.6 & \\
$(\mathrm{~A})$ & 137.7 & 24.1 \\
$10^{4} \times \mathrm{A} / \mathrm{V}$ & & 24.9 \\
\hline
\end{tabular}

Protoplasts counted: $197^{*}$ and $132 * *$.

Only results for the region B (see Fig. 2) were reported.

therefore necessary to express the RNase activity as regards to a relative unit of volume. The calculated values - for region $B$ only - are indicated in Table 4 where it can then be noticed, that the RNase activity of the mechanically prepared protoplasts is, in the average, five times stronger. It is clear, therefore, that the use of enzymes - in order to obtain protoplasts - reduced the activity of their RNases. This observation shows that, by generalizing it, the physiological properties of protoplasts depend on the technique used for their preparation.

Transaminase. Results similar to the preceding ones have been obtained (Table 5). Differences observed between the mechanical and the enzymatical protoplasts remain insignificant, but averages still give for the first, higher values. A comparison between the protoplasts on the three regions shows a significant gradient, similar to that obtained for the root cells, with a decreasing activity when passing from regions $A$ to $C$. The relative activity - for protoplasts on region $B$ (Table 6) confirms what had been observed in the case of RNases: By using enzymes for isolating protoplasts, the transaminase activity is reduced by at least $4 / 5$ in comparison with the mechanical protoplasts.

\section{Conclusion}

The present work brings into evidence certain properties of root protoplasts as compared to those of cells from which they have been prepared. First of all and as regards RNase and transaminases, the respective activities are similar but on a smaller scale. It clearly appears when the activity is brought down to a volume unit, that it is significantly lower in contrast with the absolute values. On the other hand, the activity of protoplasts, mechanically prepared, is always higher than that of the enzymatical protoplasts. The use of enzymes (maceroenzyme and cellulases) for obtaining protoplasts has, without any possible doubt, an inhibitory effect. Further, the mechanical protoplasts are smaller because the breaking of the walls brings about their fragmentation.

It appears necessary to add that the differences observed between the protoplasts mechanically and enzymatically prepared may also be due to several other causes than the sole action produced by the enzymes used. It is not to be excluded, for instance, that the two techniques may have yielded protoplasts from different types of cells for a similar region of the roots. On the other hand, the lower RNase and 
transaminase activities in the enzymatically prepared protoplasts was related to the fact that it takes as long as $12 \mathrm{hr}$ to obtain them, while the mechanically prepared protoplasts can be isolated almost immediately.

So as to account for the differences in the relative enzymatical activity observed between the cells and the two kinds of protoplasts which have been prepared a few additional comments may be suggested. A part of the cell RNases and transaminases are certainly sited in the cell walls (33). This fraction is evidently inexistent now in the protoplasts, an observation which explains such a decrease in the enzyme activity. This hypothesis is supported by the fact that certain enzymes have been brought into evidence, from the cytochemical and biochemical point of view, in the walls: phosphatase $(34,35)$, peroxidase $(36,37)$, invertase $(38)$, without mentioning all those which participate directly in the elaboration of walls (39).

But one may not either exclude that cofacting enzymes also exist in the walls (40). In this case, their absence would inevitably correspond to a loss in enzyme activity. On the other hand, the fact of taking away the cell wall to obtain protoplasts puts the plasmalemma in a new situation which can only bring about structural and functional alterations in this plasmic membrane.

\section{References}

(1) Cocking, E. C.: A method for the isolation of plant protoplasts and vacuoles. Nature 187: 927-929 (1960).

(2) Gregory, D. W. and E. C. Cocking: The large scale isolation of protoplasts from immature tomato fruit. J. Cell. Biol. 24: 143-146 (1965).

(3) Takebe, I., Y. Otsuki and S. Aoki: Isolation of tobacco mesophyll cells in intact and active state. Plant \& Cell Physiol. 9: 115-124 (1968).

(4) Schmitt, C., M. Kopp et L. Hirth: Aptitude de diverses souches de tissus de plantes cultivées in vitro a donner des protoplastes. C. R. Acad. Sc. Paris 272: 2447-2450 (1971).

(5) Chopeau, J. et G. Morel: Obtention de protoplastes de plantes supérieures a partir de tissus cultivés in vitro. C. R. Acad. Sc. Paris 270: 2659-2662 (1970).

(6) Prat, R.: Contribution à l'étude de protoplastes de végétaux supérieurs. I. Effet du traitement d'isolement sur la structure cellulaire. J. Microscopie (en prep.).

(7) Klercker: Eine Methode zur Isolierung lebender Protoplasten. Oefiers Vet. Akad. 45: 463475 (1892):

(8) Townsend, Ch.: Der EinfluB des Zellkerns auf die Bildung der Zellhaut. Jahrb. Wiss. Bot. 30: 484-510 (1897).

(9) Plowe, J. A.: Membranes in the plant cell: 1-Morphological membrane at protoplasmic surface, 2-Localisation of differential permeability in the plant protoplast. Protoplasma 12: 196-220 and 2221-240 (1931).

(10) Cocking, E. C.: Plant Protoplasts, in Viewpoint Biol. 4, p. 170-203, J. D. MacCarthy \& B. C. L. Duddington, Ed., Vol. 4, London, Butterworth \& Co. Ltd. (1965).

(11) Cocking, E. C.: Electron microscope study on isolated plant protoplasts. Z. Naturforschg. 21 b: 581-584 (1966).

(12) Mohr, W. and E. C. Cocking: A method for preparing highly vacuolated senescent and damaged plant tissue for ultrastructural study. J. Ultrastructure Research 21: 171-181 (1968).

(13) Ben Badis, A.: Aspects ultrastructuraux et culture in vitro de protoplastes de mesophylle de Tabac (Nicotiana tabacum L. GV. Wis. 38). C. R. Acad. Sc. Paris 273: 797-800 (1971).

(14) Cocking, E. C.: The action of 3-indoleacetic acid on isolated protoplasts. In "Biochemistry and Physiology of Plant Growth substances". The Runge Press, Ottawa, pp. 603-609 (1968).

(15) Cocking, E. C.: Protoplasts. Ann. Rev. Plant Physiol. (in press) (1972). 
(16) Heller, R.: Recherches sur la nutrition minérale des tissus cultivés in vitro. These. Ann. Sc. Nat. Bot. 14: 1-218 (1953).

(17) Pilet, P. E.: Aging in relation to auxin and RNA. Experientia 25: 1036 (1969).

(18) Pilet, P. E. and A. Nougarede: RNA, structure, infrastructure et geotropisme radiculaire. Physiol. vég. 8: 277-300 (1970).

(19) Humphries, E. C. and A.W. Wheeler: The effects of kinetin, gibberellic acid and light on expansion and cell division in leaf disks of dwarf bean. J. Exp. Bot. 11: 81-85 (1960).

(20) Prat, R. et J. C. Roland: Isolement mécanique et étude ultrastructurale préliminaire de protoplastes végétaux. C. R. Acad. Sc. 271: 1862-1865 (1970).

(21) Prat, R. et J. C. Roland: Etude ultrestructurale des premiers stades de néoformations d'une enveloppe parles protoplastes végétaux séparés mécaniquement de leur paroi. C. R. Acad. Sc. 273: 165-168 (1971).

(22) Power, J. B. and E. C. Cocking: Isolation of leaf protoplasts: macromolecule uptake and growth substance response. J. Exp. Bot. 21: 64-70 (1970).

(23) Nagata, T. and I. Takebe: Cell wall regeneration and cell division in isolated tobacco mesophyll protoplasts. Planta 92: 301-308 (1970).

(24) Pilet, P. E. and R. Braun: Ribonuclease activity and auxin effects in the Lens root. Physiol. Plant. 23: 245-250 (1970).

(25) Truelsen, T. A.: Indoleacetic acid-induced decrease of the ribonuclease activity in vivo. Physiol. Plant. 20: 112-119 (1967).

(26) Pilet, P. E.: Efiet in vivo du fluor sur l'activité transaminasique. C. R. Acad. Sc. (Paris) 271 : 300-303 (1970).

(27) Pilet, P. E. and M. Athanasiades: Activité transaminasique des racines du Lens culinaris. C. R. Acad. Sc. (Paris) 262: 1090-1093 (1966).

(28) Pilet, P. E.: RNA metabolism and fluoride action. Fluoride 3: 153-159 (1970).

(29) Mesquita, J. F. M.: Ultrastructure do meristema radicular de Allium cepa L. es suas alteraçoés enduzidas por agentes mitoclasecos e radiomimetices. Rev. Facult. Ciencias, Coimbra 49: (1970).

(30) Sitte, D.: Zellfeinbau bei Plasmolyse. II. Der Feinbau der Elodea Blattzellen bei Zucker und Conenplasmolyse. Protoplasma 57: 304-333 (1962).

(31) Pilet, P. E.: Transaminase activities of root protoplasts. Experientia, in press (1972).

(32) Pilet, P. E.: Acide abscissique et activité transaminasique. Experientio 27: 880-881 (1971).

(33) Pilet, P. E.: Effets de quelques auxines sur les protoplastes racinaires. C. R. Acad. Sc. 273: 2253-2256 (1971).

(34) Poux, N.: Localisation d'activités enzymatiques dans le méristème radiculaire de Cucumis Sativus L. III. Activité phosphatasique acide. J. Microscopic 9: 407-434 (1970).

(35) Golberg, R.: Etude de l' activité phosphatasique des parois de suspension d'Acer pseudoplatanus cultive in vitro (en preparation) (1972).

(36) Czaninski, Y. et A. M. Catesson: Activités peroxydasiques d'origines diverses dans les cellules d'Acer pseudoplatanus (tissus conducteurs et cellules en culture). J. Microscopie 9: 1089-1102 (1970).

(37) Poux, N.: Localisation d'activites enzymatiques dans les cellules du méristème radiculaire de Cucumis sativus L. II. Activité peroxyclasique. J. Microscopie 8: 855-866 (1969).

(38) Ricardo, C. P. P. and T. A. Rees: Invertase activity during the development of carrot roots. Phytochemistry 3: 233-247 (1970).

(39) Lamport, D. T.: Cell Wall Metabolism. Ann. Rev. Plant Physiol. 21: 235-270 (1970).

(40) Pilet, P. E.: In Les parois cellulaires. Doin Ed. 173 p. Paris, (1971). 